\title{
СУЧАСНІ МІЖНАРОДНО-ПРАВОВІ СТАНДАРТИ БОРОТЬБИ 3 НАЙМАНСТВОМ
}

\author{
МАРТЬЯНОВ Сергій Сергійович - аспірант кафедри кримінального права \\ та процесу Львівського торговельно-економічного університету \\ СКРЕКЛЯ Леся Іванівна - к.ю.н., доцент кафедри теорії держави і права \\ ЛЬвівського торговельно-економічного університету
}

DOI:10.32782/LAW.2020.1.21

В данной статье осуществлено рассмотрение и анализ современнъх международно-правовыхх стандартов уголовной ответственности за наемничество. На основе обрашения к универсальныл источникам международного публичного права, найдено широкую политико-правовую проблематичную сушность указанного вопроса.

Рассмотрена историческая трансбормачия понятия «наёмничество» в международном праве, поскольку недавние изменения в сочиальной и политической ситуачии в Украине дали новыц толчок для изучения проблем противодействия наемничеству как типичного спутника современнъих вооруженнъих конфликтов. Правовая природа наемничества охватвивает отношения в политической, международно-правовой, уголовной и правовой сферах.

На сегодняшний день Международная конвениия о борьбе с вербовкой, использованием, бинансированием и обучением наемников, принятая в 1989 году, является ключевъим документом, который устанавливает запрет наемнической деятельности. Раскрыто признаки понятия «наемник».

Ключевъе слова: наемничество, наемник, уголовная ответственность, субъект преступления, международнъй опът.

Постановка проблеми

Суспільна і соціальна небезпека найманства полягає в тому, що всупереч існуючим принципам і нормам національного і міжнародного права існує особлива «каста» людей, для яких професією стає здійснення вбивств, завдавання шкоди здоров'ю іншої людини або групи людей під час воєнних дій, збройних конфліктів, терористичних актів, знищення об'єктів економіки, культури, майна цивільного населення тощо [1, с.227]. У зв'язку з Російською збройною агресією проти України набули поширення випадки злочинної діяльності іноземців-професіоналів, яких використовують спецслужби РФ для екскалації бойових дій на Сході України. Так, у 2016 р. член робочої групи ООН 3 питань використання найманців зазначила про участь 176 іноземних найманців на боці так званих «ภНР» та «ДНР» 3 таких держав як Сербія, Білорусія, Франція, Бразилія тощо [2]. Результати опитування 94 військовослужбовців, які пережили ситуацію військового полону на Сході України, засвідчили, що під час їх допиту бойовики залучали найманців, 3 причини зняття відповідальності з себе та свого підрозділу за скоєння військових злочинів. Допит професійними найманцями характеризувався тортурами та вбивствами військовополонених з метою демонстрації сили. Характерною особливістю такого допиту була нажива, а для прискорення викупу або обміну полоненого до нього найманцями застосовувалися знущання та шантаж [3, с.316-317].

Існує коло проблем, які виходять за межі матеріалу, що стосується кримінального права. Вони заслуговують на увагу 3 
огляду на те, що і міжнародне кримінальне право, і національне кримінальне право за основний предмет мають злочин i покарання за нього [4, с.216]. Не можна заперечувати того, що проблема протидії найманству на міжнародному рівні піднімається з новою силою, оскільки у різних куточках планети, де мають місце збройні протистояння, міжнародні спостерігачі фіксують присутність спеціально завербованих іноземців професіоналів, які беруть участь у насильницьких акціях із метою дестабілізації громадської безпеки тієї чи іншої держави або зміни ії конституційного ладу [5, с.141].

\section{Стан дослідження}

Загалом дослідження проблеми найманства носить міжгалузевий характер, оскільки здійснювались 3 позицій міжнародного права, політології, теорії та історії держави і права, а також кримінального права. Власне питанню міжнародно-правової регламентації боротьби 3 найманством, а також правового регулювання діяльності приватних військових та охоронних підприємств присвятили увагу такі вчені як К.В.Громовенко, І.О. Колотуха, І.Л. Невзорова, Л.О. Павлова, П.І. Репешко, О.О. Скрильник та інші. Слід віддати належне монографічному дослідженню О.В. Наден, у якому автор розглядає найманство як соціальне та кримінальноправове явище, аналізує сучасні проблеми розвитку протиправної військової служби та найманства як його складової частини, а також характеризує найманство 3 погляду принципів міжнародного права [6]. Праці вищенаведених авторів важко переоцінити, втім вони не можуть слугувати ключем для розв'язання ряду дискусійних питань, оскільки більшість положень у них носять констатуючий характер або ж фрагментарно висвітлюють окремі питання.

Таким чином, основною метою цієї статті $є$ вивчення сучасних міжнародноправових стандартів боротьби 3 найманством.

\section{Виклад основних положень}

Незважаючи на те, що найманство $є$ поширеним негативним явищем у світі, яке несе загрозу мирним взаємовідносинам між державами, втім доводиться констатувати про відносно невелику кількість випадків засудження за найманську діяльність та не надто суворі покарання. Приміром, перед сербським судом постали 24 особи, які брали участь у бойових діях на Сході України, серед яких лише троє засуджено до шести місяців обмеження волі, a решту - до трьох років умовного відбування покарання. 3 цього приводу фахівець із питань боротьби проти тероризму Белградського центру для політики безпеки А.Стефанович висловився, що бойовиків із Сирії могли покарати і до десяти років позбавлення волі, що передбачено доповненням до КК, втім прокуратура вимагала легшого покарання, тобто спробувала домовитись із обвинуваченими, щоб вони погодились на вирок суду та процес було якомога швидше закрито [7]. Схожа ситуація мала місце і в Італії, де Генуезький суд ухвалив вироки трьом найманцям, які воювали на боці так званих $\curlywedge$ нР та ДНР. Двох із них, які займалися вербуванням найманців, засуджено до двох років та восьми місяців ув'язнення, а третього, який безпосередньо брав участь у насильницьких діях - на один рік і чотири місяці [8]. Такі приклади власне є свідченням формального підходу до здійснення правосуддя, а надмірно м'які міри покарання не є ефективним інструментом у протидії цьому злочинному та ганебному явищу.

У міжнародному праві $\epsilon$ ціла низка документів загального характеру, які регламентують питання боротьби із найманством, а зокрема: Конвенція про права i обов'язки нейтральних держав та осіб у разі сухопутної війни від 18 жовтня 1907 р., Статут Організації Об'єднаних Націй від 26 червня 1945 р., Декларація про принципи міжнародного права, що стосуються дружніх відносин та співробітництва між державами відповідно до Статуту Організації Об'єднаних Націй від 24 жовтня 1970 р., Додатковий протокол до Женевських конвенцій від 12 серпня 1949 


\section{Кримінальне право, кримінальний процес та криміналістика}

року, що стосується захисту жертв міжнародних збройних конфліктів від 8 червня 1977 р., Резолюції Генеральної Асамблеї і Ради Безпеки Організації Об'єднаних Націй (Резолюція 419 (1977) від 24 листопада 1977 р., Резолюція 36/103 від 9 грудня 1981 р. тощо).

Приміром, у Декларації про принципи міжнародного права, що стосуються дружніх відносин та співробітництва між державами відповідно до Статуту ООН від 24 жовтня 1970 р. вказано, що держави мають утримуватись у своїх міжнародних відносинах від погрози силою або іï використання як проти територіальної цілісності чи політичної незалежності будьякої держави, так і як будь-яким іншим способом, несумісним із цілями ООН. Окрім того, вони повинні утримуватись від організації чи заохочення організації іррегулярних сил чи озброєних банд, у тому числі найманців, для вторгнення на територію іншої держави. Відповідно до ст.3 Резолюції Генеральної Асамблеї ООН №3314 (XXIX) від 14 грудня 1974 р. засилання державою або від імені держави озброєних банд чи найманців, які здійснюють акти застосування збройної сили проти іншої держави слід розглядати як прояв агресії. У зв'язку 3 цим було виокремлено різновиди агресії: пряма і непряма. Відмінність між ними полягала у тому, що в першому випадку має місце застосування збройної сили держави в особі власних регулярних збройних сил. Натомість, у другому випадку держава застосовує агресію потай, шляхом використання банд чи найманців [9, с.482]. Схоже положення передбачено у Резолюції Генеральної Асамблеї ООН від 20 грудня 1968 р. №2465, у якій зазначається, що практика використання найманців проти рухів за національне визволення і незалежність 6 кримінально-караним діянням, а самі найманці оголошуються злочинцями та перебувають поза законом. 3 огляду на це рекомендовано здійснити ухвалення законів, що встановлюють відповідальність за набір, фінансування та навчання найманців.
Втім одним із ключових міжнародноправових актів, який встановлює заборону найманської діяльності є Міжнародна конвенція про боротьбу 3 вербуванням, використанням, фінансуванням і навчанням найманців від 14 грудня 1989 р. Власне у цьому документі (ст.1) розкриті ознаки поняття найманець, до яких слід відносини наступні:

1) є спеціально завербованою на місці або за кордоном особою, щоб брати участь у збройному конфлікті;

2) керується головним чином бажанням одержати особисту вигоду і якій дійсно обіцяно стороною або за дорученням сторони, що перебуває у конфлікті, матеріальну винагороду, що істотно перевищує винагороду, яка обіцяна чи виплачується комбатантам такого ж рангу і функції, які входять до особового складу збройних сил даної сторони;

3) не 6 ні громадянином сторони, що перебуває у конфлікті, ні особою, яка постійно проживає на території, що контролюється стороною, яка перебуває у конфлікті;

4) не входить до особового складу збройних сил сторони, що перебуває у конфлікті;

5) не послана державою, яка не є стороною, що перебуває у конфлікті, для виконання офіційних обов'язків як особи, яка входить до складу їі збройних сил.

Окрім того поняття «найманець» означає також будь-яку особу, яка спеціально завербована на місці або за кордоном для участі у спільних насильницьких діях, спрямованих на повалення уряду або інший підрив конституційного порядку держави або підрив територіальної цілісності держави; беручи участь у таких діях, керуються головним чином бажанням одержати значну особисту вигоду і яка спонукається до цього обіцянкою виплати або виплатою матеріальної винагороди; не $\epsilon$ ні громадянином, ні постійним жителем держави, проти якої спрямовані такі діï; не надіслана державою для виконання офіційних обов'язків; не входить до особового складу збройних сил держави, на території якої здійснюються такі дії. Схоже 
визначення поняття найманця передбачене також у ст.47 Додаткового протоколу до Женевських конвенцій від 12 серпня 1949 року, що стосується захисту жертв міжнародних збройних конфліктів від 8 червня $1977 \mathrm{p}$.

Втім доводиться констатувати, що нерідко складно здійснити розмежування поняття «найманець» від поняття «доброволець». Ще більше ускладнює ситуацію наявність у світі так званих приватних військових компаній. Більшість закордонних оглядачів відносять їх до однієї 3 форм найманства і ставлять їх в один ряд із терористами, оскільки відсутній контроль за професійною діяльністю останніх, яка в багатьох випадках за об'єктивними та суб'єктивними ознаками співпадає з найманством $[10$, с.71; 11, с.142]. Варто звернути увагу на те, що до послуг ПВК досить часто звертається ООН. Зокрема, вони залучалися у миротворчих місіях у Боснії та Герцеговині (1996-2002). У Судані (20052011) ПВК займалися проведенням гуманітарного розмінування $[12$, с.34]. Скажімо, американська ПВК «Xe Services LLC» за дорученням уряду США виконала понад 80000 спеціальних місій та завдань у різних ворожих регіонах землі [13].

Фахівці Женевського центру демократичного контролю над збройними силами розглядають приватні військові компанії як комерційну структуру, що пропонує спеціалізовані послуги, які пов'язані 3 участю у війнах і військових конфліктах, включаючи бойові операції, стратегічне планування, збір розвідувальної інформації, оперативну підтримку і логістику, підготовку, постачання, поставки, обслуговування. Власне їх характерними особливостями вважають організаційну структуру (є зареєстрованими комерційними підприємствами) та мотивацію (надають свої послуги головним чином для отримання прибутку, а не через політичні чи інші причини) [14]. 3 вищенаведеного можна зробити висновок, що ПВК мають схожі риси із загонами найманців, а саме: надання військових послуг; отримання прибутку. Втім основною відмінністю перших від других $є$ те, що ПВК мають усі необхідні ліцензії для здійснення відповідної діяльності та є офіційно зареєстрованою структурою. Про це зазначається у «Документі Монтре про відповідні міжнародно-правові зобов'язання і передові практичні методи держав, які стосуються функціонування приватних військових і охоронних компаній в період збройного конфлікту», прийнятого від 17 вересня 2008 р., де описано правила надання послуг співробітниками ПВК, серед яких виокремлено наступні: застосування сили або вогнепальної зброї можливе лише у випадку необхідної самооборони або третіх осіб; негайне інформування компетентних органів і співпраця з ним у випадку застосування сили; вимога реєстрації зброї, включаючи ії серійні номера і калібр тощо (ст.43) [15]. 3 вищенаведеного випливає, що фактично діяльність співробітників ПВК $є$ в рамках закону, тоді як найманська діяльність 6 поза законом. У науковій літературі з цього приводу відзначається, що ПВК контролюється державою та працює в її інтересах [16, с.212]. Однак варто зауважити, що, так званий Документ Монтре, має лише рекомендаційний характер і фактично розроблявся в інтересах держав (США, Франція, Велика Британія, Південно-Африканська Республіка), які користуються попитом ПВК з метою легітимізувати їх діяльність. Втім законодавство України, як і більшості держав світу, не визнає існування приватних військових компаній, оскільки «Функція 3 ведення військових дій належить виключно державі» [17].

Не можна виключати можливості, що співробітники ПВК можуть виходити «за межі своїх повноважень». На це, зокрема, звертають увагу фахівці Женевського центру демократичного контролю над збройними силами, зазначаючи наступне: «якщо ж вони потрапляють під статус осіб, які брали участь у ворожих діях або як найманці, вони будуть осуджені як «вороги» і не зможуть скористатися захистом як цивільні особи» [14]. Яскравим прикладом цього є діяльність ПВК зі США під назвою Blackwater, працівники якої чинили жорстокі розправи над цивільним на- 


\section{Кримінальне право, кримінальний процес та криміналістика}

селенням Іраку. Внаслідок їх злочинних дій урядом було відкликано ліцензію [18]. Не можна також не згадати про так звані ПВК «Патріот», «МАР», «Група Вагнера», «Слов'янський корпус», які не мають жодного юридичного статуту. Втім за їх участю ведуться бойові дії на Сході України, а також здійснювалась окупація АРК.

\section{Висновки}

Таким чином прояви найманства $\varepsilon$ рушійною силою агресії, що веде до дестабілізації міжнародного правопорядку та разючим прикладом нехтування правами і свободами людини. Проблема загострюється ще й тим, що найманська діяльність «переплітається» 3 іншими формами злочинних проявів, зокрема, такими як участь у складі непередбачених законом воєнізованих або збройних формувань чи терористичній групі або організації, що ускладнюе процес кримінально-правової кваліфікації. 3 огляду на це пошук шляхів кримінально-правової протидії проявам найманства $\epsilon$ необхідним та затребуваним.

\section{Література}

1. Мохончук С. Юридичний склад найманства та його особливості в системі злочинів проти миру та безпеки людства. Питання боротьби зі злочинністю. Вісник №2 (69). 2012 р. С.227-236

2. Preliminary findings by the UN Working Group on the use mercenaries on his Mission to Ukraine. URL: https://www.ohchr. org/EN/NewsEvents/ Pages/DisplayNews. aspx? NewsID = 18492\&LangID = E.

3. Широбоков Ю.М. Стадії військового полону та особливості їх впливу на психіку військовослужбовців. Проблеми екстремальної та кризової психології. Вип. 20. 2016 p. C.313-322.

4. Навроцький В.О. Основи кримінально-правової кваліфікації: навч. посібник] / В. О. Навроцький. - К.: Юрінком Інтер, 2006. - 704 c.

5. Юртаєва К. В. Кваліфікація найманства: національний та міжнародноправовий аспекти. Форум права: електрон. наук. фахове вид. 2018. № 3. С. 141-148.
6. Наден О.В. Найманство як соціальне та кримінально-правове явище: сутність, новітні тенденції розвитку та проблеми протидії. Монографія - К.: Атіка, 2005 264 c.

7. Чому сербських «найманців» 3 Донбасу покарали несуворо? NEWS Україна. URL: https://www.bbc.com/ukrainian/features-38211680

8. В Італії засудили трьох найманців, які воювали у лавах бойовиків на Донбаci. URL: https://tsn.ua/svit/v-italiyi-zasudili-troh-naymanciv-yaki-voyuvali-u-lavahboyovikiv-na-donbasi-1372152.html

9. Организация Объединенных Наций: Сборник документов / Ответ, ред. В. В. Вахрушев. М.: Наука, 1981.- 648 с.

10. Пунда О.О. Збройне найманство: публічно та приватноправовий аспекти. Університетські наукові записки. №2 (18). 2006 p. C.69-74

11. Юртаєва К.В. Кваліфікація найманства: національний та міжнародно-правовий аспекти. Форум права. 2018 р. №3. C. 141-148

12. Горовенко В., Тютюнник В. Приватні воєнні компанії: міжнародний досвід і можливі шляхи його реалізації в Україні. Наука і оборона. №3. 2013 р. С.32-39.

13. Government Services : [Урядові послуги : інформ. матеріали з сайту приват. військ. компанії «3i»]. URL: http://www.xecompany.com/ Government_Services

14. DCAF Backgrounder. Приватні військові компанії. Женевський Центр демократичного контролю над збройними силами. URL: https://www.files.ethz.ch/ isn/17438/bg_private-military-companies ukr.pdf

15. «Документ Монтре про відповідні міжнародно-правові зобов'язання і передові практичні методи держав, які стосуються функціонування приватних військових і охоронних компаній в період збройного конфлікту» від 17 вересня 2008 p. URL: https://www.icrc.org/ru/doc/assets/ files/other/montreau.pdf

16. Невзоров I.Л., Хотенець П.В. Приватні військові компанії та право: гострі питання, деякі світові тенденції нормативного регулювання. Підготовка охорон- 
Мартьянов С.С., Скрекля Л.І. - Сучасні міжнародно-правові стандарти боротьби...

\section{АНОТАЦІЯ}

У даній статті здійснюється грунтовний розгляд та аналіз сучасних міжнародно-правових стандартів кримінальної відповідальності за найманство. На основі звернення до універсальних джерел міжнародного публічного права, виявлено широку політико-правову проблематичну сутність означеного питання.

Розглянуто історичну трансбормачіюо поняття «найманство» у міжнародному праві, оскільки нещодавно зміни в сочіальній та політичній ситуачї̈ в Украӥні дали новий поштовх для вивчення проблем протидї найманству як типового супутника сучасних збройних конббіктів. Правова природа найманства охоплює відносини в політичній, міжнародноправовій, кримінальній та правовій сферах.

На свогоднішній день Міжнародна конвенчія про боротьбу з вербуванням, використанням, бінансуванням і навчанням найманиів, прийнята в 1989 рочі, є ключовим документом, який встановлюе заборону найманської діяльності. Розкрито ознаки поняття «найманець».

Ключові слова: найманство, найманещь, кримінальна відповідальність, суб'єкт злочину, міжнародний досвід.

ців правопорядку в Харкові (1917-2017 р.) Харків. 2017 р. С.212-214.

17. Скрильник О.О., Штепа О.І. Правовий статус учасників міжнародного

\section{SUMMARY}

In the present paper the author thoroughly considers and analyses the present international legal standards of criminal liability for infringement of a state's territorial integrity. In accordance with universal sources of international public law the author determines a wide political and legal problematic sense of the issue under consideration. Recently changes in social and political situation in Ukraine have provided a new impetus to studying problems of counteracting mercenarism as a typical concomitant of contemporary armed conflicts.

Legal nature of mercenarism encompasses relationship in political, international and legal, criminal and legal spheres. At the present moment International Convention against the recruitment, use, financing and training of mercenaries adopted in 1989 is the basic international document, which criminalizes mercenarism. Although its ratification list is not very big, any countries provide severe punishments for mercenarism and related practices.

Key words: mercenarism, mercenary, criminal responsibility, subject of the crime, international experience.

збройного конфлікту: актуальні аспекти. Журнал східноєвропейського права. 2016. № 27. C. 101-105.

18. Abrisketa J. Blackwater: mercenaries and international law. Fride, 27 September 2007. URL: http://fride.org/download/blackwater.english.pdf. 